Volume 27, 2017

http://journals.sfu.ca/cjsdw

\title{
Article
}

\section{The Once and Future Writing Centre: A Reflection and Critique}

\author{
Anthony Paré \\ University of British Columbia
}

Despite nearly four decades of teaching and studying writing, including many years as a writing centre instructor and director, I really don't know what will happen to Canadian writing centres, and I am also uncertain about what should happen. However, I have some reflections on our past, some concerns about how we got here, and some thoughts about how we might move forward ${ }^{1}$. I should acknowledge that the criticisms I offer here began in self-reflection: looking back over my work in a writing centre, I recognize that I have been guilty of all that I describe in the following pages. But I haven't been alone.

Who is this collective I have evoked by using "our" and "we"? Is there any sort of community with sufficient coherence and consistency to share my guilt? My imagined audience includes members of the Canadian Association for the Study of Discourse and Writing (CASDW), the Canadian Association for the Study of Language and Learning (CASLL), the Canadian Writing Centres Association (CWCA), the Canadian Society for the Study of Rhetoric (CSSR), and the many people who support writing in Canadian universities but belong to no national organization. However, as Roger Graves noted in 1994, as the authors in Graves and Graves (2006) confirmed, and as Dana Landry (2016) has demonstrated in her doctoral research, there is nothing like a unified approach to or theory of writing across the broad Canadian scene. Still, as I reflect on the more than 40 writing-related conferences I have attended, the five Canadian writing centres/programs I have visited as an external reviewer, and the hundreds of articles, chapters, books, and posts I've read about writing, the issues I raise here strike me as prevalent, if not universal. Like all writers, I leave it to individual readers to identify or not. 
Volume 27, 2017

http://journals.sfu.ca/cjsdw

I should start by saying that I feel we in Canada have, by and large, failed to convince university administrators and colleagues in the disciplines of the essential value of our work, and we need to ask ourselves why that is so. With few exceptions, writing centres and programs across Canada have had to struggle to establish and maintain themselves. And even after four decades of that effort ${ }^{2}$, many of those who work to support student writing in universities are still stuck on the margins. They remain, in Susan Miller's (1991) poignant phrase, the "sad women in the basement." Moreover, our writing centres - always peripheral, despite their claim to centrality - are disappearing into student services, learning commons, and academic support units3.

This phenomenon has been thoughtfully and thoroughly considered (e.g., Graves \& Graves, 2006), and there may be advantages to marginality - opportunities to teach "under the curriculum" (p. 380), as Russ Hunt put it (2006) - but the dispersion of writing support in universities has not led to institutional power and funding 4 . And despite the emergence of the discipline of writing studies, we in Canada remain largely untethered in the academy and are too often seen as service units and not centres of scholarship. Our diffuse presence might well be in keeping with a post-disciplinary world, but our institutions, our degree programs, and our curricula remain solidly disciplinary.

That is not to say that our work has been a failure. On the contrary, in many ways that we have neglected to adequately document, we have provided solace, insight, and essential support to students. We have witnessed their relief and received their testimonies to the positive effects of our courses, our tutoring, and our workshops. With scant resources but lofty ideals, we have stretched ourselves thin to catch those many students who fall through the university's cracks. We believe strongly that what we do has value, and that makes the failure to secure our colleagues' understanding and support seem particularly cruel. We have assumed that writing is critical in the academy, and we have worked hard to teach and study it.

As a result of our deep conviction and altruistic goals, however, there has been an evangelical fervour in North American writing studies that Canadians have not been able to avoid - a strong sense of mission and dedication and a deep belief that we could make the academy a more just, more humane, more egalitarian institution, if only writing were 
Volume 27, 2017

http://journals.sfu.ca/cjsdw

recognized as central to knowledge-making. This is what Susan Miller called the "morally correct seriousness of composition studies" (1991, p. ix). And like other true believers whose faith has been ignored, marginalized, or suppressed, we have often taken on the mantle of victim. In conference sessions, faculty meetings, listserv exchanges, and other forums, lamentations about funding, hiring, salaries, recognition, and support have been a common theme among us. We have, at times, been sullen and resentful, and have stood apart from our university colleagues.

A further consequence of our zeal has been a tendency to be inflexible, even occasionally dogmatic, in our adherence to theory and pedagogy. Rejecting the so-called "product approach" for a "process approach" in the 1970s put us on the side of the angels, and introduced the possibility of heresy in the discussion of writing instruction. Those who favoured form over process were tied to the stake. The ensuing and heady renaissance in writing process theory, research, and pedagogy (e.g., Elbow, 1973; Emig, 1971; Flower \& Hayes, 1977; Murray, 1980) convinced us that we had found a better way. However, the subsequent rejection of a narrow process approach in the 1980s, especially that branch of it influenced by cognitive psychology, produced a further purging of nonbelievers (e.g., Berlin, 1988; Bizzell, 1982, 1986; Carter, 1988). Perhaps rejecting past belief and embracing new truth is typical of all fields of academic endeavour, but I have often sensed an intolerance among those of us working in writing that has led to an usversus-them division and an unwillingness to collaborate with others. This has made us complicit in our own marginalization.

We have also conspired to lower our own status by offering those miracle writing cures that our colleagues hope will repair their broken students: the one-off workshops, the writing-tip sheets, the guest lectures, the writing "clinics," the remedial courses, the one-on-one tutoring services, and the other solutions to someone else's idea of the "problem" with student writing. Giltrow (2016) offers this account:

In some ways, writing studies and writing centres have cooperated in their own exposure by accepting, you might say, campaign donations from unreliable sources. Among the most treacherous of these are the literacy alarmists and language purists; the advocates of grammar instruction with a hint of literary 
Volume 27, 2017

http://journals.sfu.ca/cjsdw

appreciation. Another source of support, more respectable and less fanatic but still undependable, are the colleagues who, perennially, want to see student writing 'improved'; the programs and departments which want what they call communication skills for their curriculum and imagine 'writing assistance' for their students. (p. 18)

Of course we don't agree with them, we know better, but funding and our precarious place in the institution requires us to look useful. So we roll our eyes, hold our noses, and do the work, all the time consoling ourselves that we will eventually correct general misunderstandings about writing and be able to implement the deep and widespread strategies that are really needed.

Unfortunately, many of the services we offer, including those that do seem to help students find their rhetorical footing in academic writing, contradict our key arguments about writing as a situated activity employed in unique ways to make disciplinary knowledge. Workshops and one-off guest lectures probably have some positive effects (or I have wasted a lot of my time). And, yes, those undergraduate and graduate students we train and employ in tutoring probably help students break free of the constraining writing habits they have learned. But can those tutors - or any of us, really - have the rhetorical sensitivity of disciplinary experts, and can insights offered so far from the scene and activity of inquiry be sustaining? As someone once said, "we don't write writing"; we write about something, in some setting, for some reason, and to some specific set of readers. Tutors and writing teachers can attend to the generalities of writing, but unless highly trained, can they be expert in the particularities? And, in any case, their assistance comes outside the context of the lab, the course, the controversy, the on-going debate, and the discourse communities that are a text's natural habitat5.

Like so many of us, I came to the teaching and study of writing through tutoring, and I don't want to leave the impression that I dismiss its value. As a graduate student thoroughly steeped in Don Murray, Don Graves, James Britton, James Moffett, Linda Flower, and John Hayes, I was pleased and confirmed by my tutees' gratitude and insights. The process approach acknowledged the complexity of writing, gave students permission to feel lost and some tools to help them move forward, and allowed them 
Volume 27, 2017

http://journals.sfu.ca/cjsdw

some measure of success. But I remember, too, that tutoring seemed oddly disembodied, divorced from the actual conversations in which academic writing participates, or aspires to participate. Like others, I encouraged process strategies - freewriting, brainstorming, concept mapping - and raised questions about purpose and audience, and that frequently seemed to work for a given student and a specific paper, but I had no way of knowing whether that success spread to other assignments.

Likewise, as a teacher in the early process era, I became convinced that the "best" students were those who performed the writing process well in my classroom, yet some of them might not have transferred that demonstrated behaviour to their work outside of my course. At the time, discussions with students indicated that they reverted to their old ways of writing: they collected lots of notes and quotes, they left writing to the very last minute, and they produced a single draft.

One response to this concern - certainly one that I employed - suggests that a more sustained attention to writing-as-rhetoric in dedicated writing courses is an improvement over one-off sessions, out-of-context tutoring, and process instruction. In such an approach, teachers don't need to be disciplinary experts so much as specialists in a form of rhetorical ethnography that allows them to help students develop the ability to read rhetorical situations wherever they may arise. Developments in genre theory have helped support this approach, and formed the basis of a writing pedagogy that sensitizes students to what might be thought of as the universal elements of the rhetorical situation: exigence, purpose, rhetor, readers/listeners, text, consequences, and so on (e.g., Devitt, 2004; Devitt, Reiff, \& Bawarshi, 2003). Armed with what we hope is a critical rhetorical consciousness, students go forth into their disciplines ready to analyse the writing situations they will meet there. Do we have evidence that this approach works, though?

Perhaps I am wrong about the impact of our services, but how would we know? Have we demonstrated the value of our work in ways that would sway colleagues and administrators, or have we dismissed all conventional ways of measuring development in writing as inaccurate or ill-conceived? Is there enough concerted, comprehensive research that offers evidence of gains made through writing tutorials, workshops, or other forms of intervention, or any comparative research that shows differences between 
Volume 27, 2017

http://journals.sfu.ca/cjsdw

students who take writing courses and those who don't, or pre- and post-studies that chart the change in our writing students over a semester? Can we prove that our work is not only helpful but essential6?

I am reaching the end of my own lamentation here, and I would like to finish on a more positive and forward-looking note. I think our best arguments for the importance and centrality of writing in the academy must be made through both research and practice, and particularly through the link between the two. Canada has a rich tradition of research into the rhetorical dynamics that produce knowledge and action in diverse settings. We need to continue building on the work of Natasha Artemeva, Aviva Freedman, Janet Giltrow, Roger Graves, Cathy Schryer, Graham Smart, Judy Segal, and others to demonstrate that discourse is the crucible of knowledge, and not merely its means of dissemination. Research remains the highest status activity in the academy, and is the basis for disciplinary prestige. We will command greater respect and attention when we can point to studies that support our claims about writing in the disciplines. That means we also need to back up claims for the efficacy of our teaching and tutoring with evidence that will sway budget-conscious administrators and dismissive colleagues. How can we help others see and know the value of our work?

Our research-based practice can also provide eloquent testimony to our work. In particular, our collaborations with colleagues in disciplinary programs should link writing to the work of knowledge-making within curricular areas. I think we need to continue to insist on the foundational role of discourse in any reasonable theory of learning and knowing. And we need to emphasize the centrality of debate, disagreement, and consensus-building (that is, the centrality of rhetoric) in disciplinary life. If we continue to treat writing as a set of discrete skills or strategies, separate from but transferable to the grunt work of knowledge-making, we will reinforce our colleagues' mistaken notions of writing as simply the way that knowledge is delivered.

The challenge has never been easy, and I don't think it will get any easier. Our institutions of higher education remain temples of the Enlightenment, and methods and disciplines are still worshipped. The belief that disciplinary modes of inquiry guarantee disinterested objectivity and produce truth may not be as prevalent as it once was, but disciplines are still protective of their sovereignty and may be threatened by the idea that 
Volume 27, 2017

http://journals.sfu.ca/cjsdw

knowledge proceeds from rhetorical practice. To achieve the level of trust and mutual respect that true interdisciplinarity demands, we need to continue to demonstrate expertise as writing researchers and scholars, and we need to build alliances with our disciplinary colleagues to develop courses and programs that locate writing instruction at the site of knowledge production.

\section{Endnotes}

1. Well into the writing and revising of this paper, I read Janet Giltrow's (2016) article on the history of Canadian writing centres, which is required reading for anyone hoping to understand the current state and possible future of writing instruction in Canada.

2. I am dating from the 1978 inception of the Canadian centre I was involved with McGill's Writing Centre; others may have preceded that.

3. I am writing here primarily of Canadian writing centres. My sense is that U.S. writing support, built on the foundation of compulsory first-year composition, is more visible and viable. In addition, writing scholarship has had a higher profile in the U.S. But the struggle to portray writing as central to scholarship and not merely a concern for remediation is on-going everywhere.

4. The writing support network at the University of Toronto might be the exception here.

5. As I argue below, our most successful instructional efforts may be those that cleave most closely to disciplinary curricula.

6. There are studies of the efficacy of U.S. writing centres, including recent research (e.g., Salem, 2014), but the context of and support for U.S. centres differs from the Canadian experience. I am unaware of Canadian studies that support claims of writing centre effectiveness.

\section{Acknowledgments}

Thanks to Judy Segal, Dawn Allen, Joel Heng Hartse, and an anonymous reviewer for helpful comments on earlier drafts of this paper. 
Volume 27, 2017

http://journals.sfu.ca/cjsdw

\section{References}

Berlin, J. (1988). Rhetoric and ideology in the writing class. College English, 50, 477-94.

Bizzell, P. (1982). Cognition, convention, and certainty: What we need to know about Writing. PRE/TEXT, 3, 213-43.

Bizzell, P. (1986). Foundationalism and anti-foundationalism in composition studies. PRE/TEXT, 7, 37-56.

Carter, M. (1988). Problem-solving reconsidered: A pluralistic theory of problems. College English, 50, 551-65.

Devitt, A. (2004). Writing genres. Carbondale, IL: Southern Illinois University Press.

Devitt, A., Reiff, M.J. \& Bawarshi, A. (2003). Scenes of writing: Strategies for composing with genres. New York, NY: Pearson/Longman.

Giltrow, J. (2016). Writing at the centre: A sketch of the Canadian history. Canadian Journal for Studies in Discourse and Writing/Rédactologie, 26, 11-24.

Graves, R. (1994). Writing instruction in Canadian universities. Winnipeg, MB: Inkshed Publications.

Graves, R. \& Graves, H. (eds.). (2006). Writing centres, writing seminars, writing culture: Teaching writing in Canadian universities. Winnipeg, MB: Inkshed Publications.

Landry, D. (2016). Writing studies in Canada: A people's history (doctoral dissertation). Retrieved from: https://open.library.ubc.ca/

Hunt, R. (2006). Afterword: Writing under the curriculum. In R. Graves \& H. Graves (eds.), Writing centres, writing seminars, writing culture: Teaching writing in Canadian universities (pp. 371-383). Winnipeg, MB: Inkshed Publications.

Miller, S. (1991). Textual carnivals: The politics of composition. Carbondale, IL: Southern Illinois University Press.

Salem, L. (2014). Opportunity and transformation: How writing centers are positioned in the political landscape of higher education in the United States. The Writing Center Journal, 34(1), 15-43. 